2013-02-12

\title{
'Moving In': Difficulties and Support in the Transition to Higher Education for In-Service Social Care Students
}

Fiona McSweeney

Technological University Dublin, fiona.mcsweeney@tudublin.ie

Follow this and additional works at: https://arrow.tudublin.ie/aaschsslarts

Part of the Higher Education Commons, and the Sociology Commons

\section{Recommended Citation}

McSweeney, F. (2013). 'Moving in': Difficulties and support in the transition to higher education for inservice social care students. Social Work Education: The International Journal. First published on: 12 February 2013 (iFirst). doi:10.1080/02615479.2013.770832

This Article is brought to you for free and open access by the Social Sciences at ARROW@TU Dublin. It has been accepted for inclusion in Articles by an authorized administrator of ARROW@TU Dublin. For more information, please contact arrow.admin@tudublin.ie, aisling.coyne@tudublin.ie,gerard.connolly@tudublin.ie.

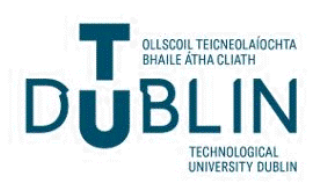


This article was downloaded by: [Dublin Institute of Technology]

On: 23 J anuary 2014, At: 06:55

Publisher: Routledge

Informa Ltd Registered in England and Wales Registered Number: 1072954 Registered

office: Mortimer House, 37-41 Mortimer Street, London W1T 3J H, UK

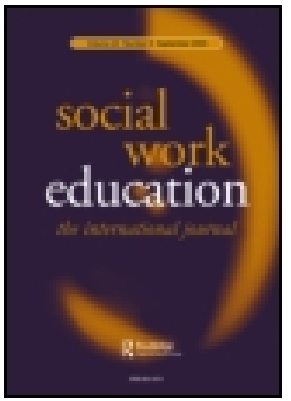

\title{
Social Work Education: The International J ournal
}

Publication details, including instructions for authors and subscription information:

http:// www. tandfonline.com/loi/ cswe20

\section{'Moving In': Difficulties and Support in the Transition to Higher Education for In-service Social Care Students}

\author{
Fiona McSweeney ${ }^{a}$ \\ ${ }^{a}$ Department of Social Sciences, Dublin Institute of Technology, \\ Dublin , Ireland \\ Published online: 12 Feb 2013.
}

To cite this article: Fiona McSweeney, Social Work Education (2013): 'Moving In': Difficulties and Support in the Transition to Higher Education for In-service Social Care Students, Social Work Education: The International J ournal, DOI: 10.1080/ 02615479.2013.770832

To link to this article: http:// dx.doi.org/ 10.1080/02615479.2013.770832

\section{PLEASE SCROLL DOWN FOR ARTICLE}

Taylor \& Francis makes every effort to ensure the accuracy of all the information (the "Content") contained in the publications on our platform. However, Taylor \& Francis, our agents, and our licensors make no representations or warranties whatsoever as to the accuracy, completeness, or suitability for any purpose of the Content. Any opinions and views expressed in this publication are the opinions and views of the authors, and are not the views of or endorsed by Taylor \& Francis. The accuracy of the Content should not be relied upon and should be independently verified with primary sources of information. Taylor and Francis shall not be liable for any losses, actions, claims, proceedings, demands, costs, expenses, damages, and other liabilities whatsoever or howsoever caused arising directly or indirectly in connection with, in relation to or arising out of the use of the Content.

This article may be used for research, teaching, and private study purposes. Any substantial or systematic reproduction, redistribution, reselling, loan, sub-licensing, systematic supply, or distribution in any form to anyone is expressly forbidden. Terms \& Conditions of access and use can be found at http://www.tandfonline.com/page/termsand-conditions 


\section{'Moving In': Difficulties and Support in the Transition to Higher Education for In-service Social Care Students}

Fiona McSweeney

This paper reports on the difficulties and supports experienced by social care practitioners within the educational institution during their transition to higher education. A life transition such as entering higher education causes stress for individuals and social support is essential in successfully dealing with this stress (Anderson et al., 2012). Fifteen social care practitioners were interviewed twice during and once at the end of their first academic year in college. Findings indicate that participants were reluctant to approach staff for help despite anxiety about classes and assignments. Discussion and debate in class helped learning and contributed to feelings of being valued. 'Moving in' was a slow process with a physical and emotional impact for which they were unprepared. Student peers were a source of emotional and cognitive support but developing relationships took time. By the end of the transition phase participants noted changes and gains in themselves and their work practices. Recommendations are made to aid the transition to higher education for in-service social care practitioners.

Keywords: transition; higher education; support; difficulty; social care education; workrelated learning; adult student

\section{Introduction}

The data presented in this paper was generated as part of a study of social identities in work-related learners. The aims of the original study were to explore how the participants interpreted and identified with the roles of social care worker and student, as well as the interaction between these two social identities. This is reported elsewhere (McSweeney,

Department of Social Sciences, Dublin Institute of Technology, Dublin, Ireland

Correspondence to: Fiona McSweeney, Department of Social Sciences, Dublin Institute of Technology, 41-44 Mountjoy Square, Dublin, Ireland. Email: fiona.mcsweeney@dit.ie 
2011, 2012). In the original study support was conceptualised as a structural factor that impacted on the student identity formed and relationship between identities, but was not explicitly examined in relation to minimising stress during the transition to higher education. This paper explores the features of the institutional environment identified by students as causing difficulties or providing support.

\section{Social Care Work and Education}

While there are similarities between social care work and social work, for example being agents of society, working with groups and individual clients, the primacy of the worker's relationship with clients in achieving change and working as part of a team (Crimmens, 1998) differences also exist. For example in social care work caring occurs within the clients' living environment (Smith, 2003); developing a therapeutic relationship is central (Anglin, 1999) and creative activities are used as tools for intervention (Davies-Jones, 2000).

The role of a social care worker in Ireland is comparable to that of as social pedagogue in mainland Europe, with the majority working with young people in residential centres. Similarly programmes of professional education are separate from those of social work (Hallstedt and Högström, 2005). In Ireland and mainland Europe qualifications at Level 7 and 8 are required for employment as a social care worker, while in the United Kingdom qualifications at Level 5 and 6 are acceptable (National Qualifications Authority of Ireland, 2005). Indeed, Bayes (2009) calls for the level of qualifications in Scotland to be raised to that of Ireland and mainland Europe.

Although educational courses in social care work have been in existence in Ireland since 1971 (Richardson, 1996), there has been an increasing drive to ensure that social care practitioners are appropriately academically qualified. Tying salary scales to possession of a relevant academic qualification (Hanafin, 2001) and the forthcoming advent of a registration board (Health and Social Care Professionals Act: Government of Ireland, 2005) have had an impact on practitioners entering higher education in terms of both finance and motivation. The cost of professional education is a significant factor. The expense to services of releasing staff to attend college and make contributions to fees has resulted in a reduction in time spent in college and fewer employers contributing towards college fees. While the participants in the research reported in this paper also cite personal reasons for entering the programme of education, the professionalization and registration of social care work is a primary factor in their decision. Viewing the entry to higher education as a transition (Anderson et al., 2012) this paper reports on institutional factors identified by students as being supportive during their first year of college.

\section{Nature of a Transition}

Anderson et al. (2012, p. 39) define a transition as 'any event or non event that results in changed relationships, assumptions, routines and roles', that is perceived by the individual involved as a transition. Although a transition in adulthood can be an 
opportunity for growth and development it may cause an element of uncertainty for the individual involved as it may 'require [... ] letting go of former roles and learning new ones' (Anderson et al., 2012, p. 40). Therefore, according to Quinlan and O’Brodovick (1996, p. 175):

Transition is a time of risk and restructuring, and the outcomes of a transition depend on the extent to which changing circumstances alter an individual's social roles, personal relationships, lifestyle routines and assumptions about themselves and the world.

Hence transitions in life have the potential to cause the person stress and 'adults in transition are often confused and in need of assistance' (Anderson et al., 2012, p. 37). The extent of the stress or anxiety caused is influenced by whether the transition is anticipated or not and the extent of the individual's coping resources. Coping resources include strategies used (for example asking for information or assistance when needed); self - the individual's personal resources and characteristics; situation for example, concurrent stresses; previous experiences; role change and feelings of control and support - types of support (Anderson et al., 2012). This paper focuses on support within the educational institution.

\section{Education as a Transition}

Commencing a higher education programme represents a transition in a person's life as it can affect existing relationships, challenge previously held views, change a person's routines and conflict with other roles, as well as lead to questioning roles. Mature students have reported feeling a "social distance" from friends and family due to a lack of common conversational topics (Merrill, 1999, p. 183) and being mocked due to changes in their vocabulary (Baxter and Britton, 2001; Stevens, 2003). Time spent with pre-existing social networks can also be reduced because of the pressures of college work (Galatzer-Levy et al., 2012) for students of all ages. Baxter and Britton (2001) and Leathwood and O'Connell (2003) found that higher education encourages questioning of the status quo which can pose risks to students' existing knowledge, requiring it to be restructured. For adult students conflict with other roles and responsibilities can occur (Tones et al., 2009). Taking part in education is reported to impinge on time spent with families and require changes in family routines (Uí Chasaide, 1997; Davies and Williams, 2001; Stevens, 2003). Conflict with time spent with partners and work is also found (Leder and Forgasz, 2004). Forrester-Jones and Hatzidimitriadou's (2006, p. 618) Community Care Practice participants stated that balancing home and work with studying contributed to stress as well as directly impacting on their studies through lack of 'time to reflect or think issues through'.

Social care work itself can be stressful as it involves working with marginalised and troubled clients. Practitioners have reported suffering from feelings of fear, anger and impotence (Knorth et al., 2007) and being unable to deal effectively with the behaviour and needs of people in their care (Heron and Chakrabarti, 2002a).

For work-related social care students conflict with their professional role can also occur, as a requirement of professional education is critical reflection on self and work, 
thus questioning of one's own work practices (Bamber and Tett, 2000). Other issues highlighted in research on work-related learning are the perception of the conflict between theoretical and practical knowledge (Martin, 2003) and the tendency of these learners to use a concrete approach to writing instead of the expected abstract and theoretical approach (Sutherland, 1999; Martin, 2003), both of which have consequences for learning and performance in college, in turn impacting on student success and identity.

As well as conflicting with other roles, relationships and views, beginning a programme of higher education can cause vulnerability as the participant forms an identity as a student (Verger et al., 2009), which is likely to require adjustment to his/her existing learner identity. For example, adult students have reported expecting teaching styles to be the directive ones of their schooldays rather than those of selfdirection and responsibility (Merrill, 1999). The process of developing a viable student identity, adjusting to college and fitting study in with other responsibilities takes time (Tones et al., 2009) so any stress experienced may be prolonged.

\section{Educational Support}

Research indicates the positive impact of various types of support on adjustment to higher education (Ramsay et al., 2007) and on academic success (Lundberg et al., 2008). Appropriate support has been found to contribute to developing feelings of mastery over one's environment and helping to reduce stress (Pearlin and Schooler, 1978). Verger et al. (2009) found a direct association between mastery and positive mental health among university students in France.

Research involving both young and adult students suggests that persistence in a higher education programme is encouraged by the students' perception of how they are valued by the institution and how well their needs are met (Walsh et al., 2009). Jacklin and Le Riche (2009, p. 735) propose that 'student support is a socially situated, complex and multifaceted concept.' They note the move away from a view of student support in higher education from focusing on deficits in students to examining the resources that students find supportive.

\section{Sources and Use of Institutional Support}

Thompson (2008) reports reluctance among college students to seek academic support from staff. This is said to be due to feelings of intimidation and fear of appearing unknowledgeable, as well as timetable conflicts. On the other hand, Walsh et al's (2009) participants cited their academic tutor as the second most frequent source of support for academic issues (with friends on the programme being the primary one), particularly among first year students of all ages. Easy accessibility to academic tutors, confidence in their ability to understand problems and the informal nature of the relationship were given as reasons for seeking assistance from tutors.

While peers are undoubtedly an available and valuable source of support for students, staff behaviour such as calling students by name and asking their opinions 
are reported to be supportive. These behaviours make students feel positive about themselves and contribute to mastery over their environment. These in turn increase motivation and improve learning. Experiencing positive emotions in relationships with lecturers also promotes valuing and using the information presented in class (Frymier et al., 1996; Frymier and Houser, 2000).

Lecturers are an important source of support, as the time limitations of part-time and adult students because of their multiple other responsibilities, as well as the availability of services at suitable times, are reported to cause difficulties in using other institutional support services (Tones et al., 2009).

\section{Methodology}

As the aim of the original research was to explore individual interpretations of their experiences and identities as social care workers and students an interpretivist methodology was used. This methodology enables understanding of the participants' construction of their experiences and worlds (MacLeod, 2001). It is also suitable for exploring perceptions of support, as support is a personal interpretation and socially situated (Jacklin and Le Riche, 2009).

\section{Participants}

All thirty-seven students who commenced the programme were invited to take part in the research. Participants were told that the researcher was their psychology lecturer for the first semester. Twenty students completed participant consent forms but five withdrew before the commencement of data collection. The mean age of participants at the beginning of the study was 35.5 years ( $S D=7.2$ years), with a range of ages from 22 to 50 years old. Nine participants were female and six male. Experience as social care workers ranged from 2 to 15 years. Participants varied with regard to their prior educational experience with seven completing previous higher education programmes (one to honours degree level), five completing further education programmes, one completing secondary school and two with no formal educational qualifications.

\section{The Educational Programme}

The programme in which participants were enrolled is three years in duration leading to the academic and professional qualification of a B.A. in Social Care Practice. The programme is work-related in that the students' work practices receive credits contributing to the award. Work practices are assessed by an assigned practice teacher who liaises with the college tutor, facilitates two tripartite meetings during the academic year and completes a placement assessment form. Students attended college for classes one day per week for the academic year. Core modules in psychology, sociology, social policy, creative studies and principles of professional practice are studied in each year of the programme. While assessment methods aim to incorporate 
reflection on and critical evaluation of practice "traditional" academic methods of essays and examinations are also used.

\section{Data Collection and Analysis}

In line with the interpretivist methodology semi-structured individual interviews were the primary method of data collection. All fifteen participants were interviewed twice during their first academic year and between their first and second year. A series of interviews was chosen as constructing an identity is an ongoing process (Pollard, 2003). Difficulties faced and views of support also changed throughout the academic year, so multiple interviews provided a more complete picture of the participants' experiences. In addition multiple interviews diluted the power relationship with participants as the researcher was no longer teaching them by the time the second interview was conducted. A relationship of equality through exchanging viewpoints and offering personal and professional opinions, if requested, was consciously maintained throughout the interviews, what Seale (1998) refers to as a feminist methodology. The interview topics were given to participants about a week beforehand and they were assured that they did not have to discuss anything they did not want to. During the interviews participants were asked about what they enjoyed about the course, difficulties encountered, sources of help and support, and the relationship between college and work. The transcripts were given to participants after each interview for their comments and to allow them to delete anything they did not want included in the analysis. Merrill (1999, p. 52) points out that this strategy is useful in creating a 'less exploitative' relationship between interviewer and participant as well as permitting continuity between interviews. No participant requested the deletion of any part of the interview.

Regarding data analysis, participants' views on difficulties encountered and supportive factors were taken at face value and personal to them congruent with the relativist epistemology of interpretivist research as well as the complexity of the notion of support (Jacklin and LeRiche, 2009).

Data was examined for participants' perceptions and interpretations of aspects of the college environment which caused difficulty or were supportive. Some similarity to the strategies proposed by Quinlan and O'Brodovich's (1996), to alleviate stress during the life and educational transition of the vocational learner was found. Quinlan and O'Brodovich argue that educators can develop supportive strategies for new students by encouraging optimism and control; facilitating self-awareness; orientating students to the institution; assisting in using social and strategic support and highlighting gains in 'roles, relationships, routines and identity' (1996, p. 177).

\section{Findings and Discussion}

Anxiety

Anxiety regarding expectations for assignments, examinations and the ability to understand content were apparent among the participants, in common with other 
studies of adult learners (e.g. Murphy and Fleming, 1998; Merrill, 2001; Leathwood and O'Connell, 2003; Moore, 2004). Due to the work-related nature of the programme concerns about how one is seen by other social care practitioners and lecturers' associating poor performance in assignments with poor work practices. are also present in participants' accounts:

We're very vulnerable. We all come from different units and we're saying are they doing the same as we're doing? Are they handling situations as we're doing? Are we as professional as they are?

You're thinking to yourself when you're writing [assignments] that if I write this she's going to think I'm crap at my job.

\section{Reluctance to Seek Support}

Previous studies show that variation is found regarding sources of support utilised (Thompson, 2008; Walsh et al., 2009). While, as will be discussed below, peers did provide support, when directly asked where they would look for help within the institution all but one participant expressed reluctance to ask anyone, citing reasons relating to their adult status and associated images of capability.

I'm not great at asking for help. [ . . . ] I'd be slow enough. I suppose I would go to the lecturer eventually. I have this image of I should be able to do it myself. I'd be embarrassed you know. I hope that's a mature student thing.

Normally I don't ask for help I just get on with things. [ ... ]. How do you ask for help? It's how do you not come across as needy or incapable and ask for help.

\section{Learning Optimism and Sense of Personal Control}

\section{Relevant Instruction}

When instruction is seen by students as clear (Frymier and Houser, 2000), relevant to their goals and conducted in a way seen as motivating their learning, students are more optimistic about learning, which in turn promotes self-efficacy (Quinlan and O'Brodovich, 1996). Numerous studies have found that adult learners want content to offer the potential for application (e.g. Donaldson et al, 1993; Migletti and Strange, 1998; Ross-Gordon and Brown-Haywood, 2000) as well as including practice examples to help the link to be made between theory and practice (Bishop-Clarke and Lynch, 1992). Due to juggling multiple roles adult students can also wish to economise their learning efforts so clear and relevant lectures are particularly important to them (Ross-Gordon, 2003).

Lecturers' enthusiasm for their subject was viewed as conducive to learning:

I found [Name] brilliant. Just the way he teaches. So alive and enthusiastic. You just catch it up like that.

The style of lecturing described as most preferred and seen as beneficial to learning was pre-reading material and using class time to discuss it: 
Last week we covered six different perspectives or different theorists' perspectives and they just came like that, no discussion, no prior reading, no nothing. About twenty minutes in to be honest I'm lost. I'm gone. [ . . ] It's an hour I feel like I have completely wasted. [...] Give us the reading the week before and go over what we read in class. Let's have a discussion about it.

Reading through lecture slides and writing notes, without being assigned specific reading to develop on it, was reported to be both unhelpful for learning and demotivating:

They stick the slides up there and basically we read through the boxes and then we go home and we have no meat to put on the boxes. No reading to do around it and you go home and you don't know what it was about. I really have nothing to support what they said to go back and read. And I find that boring and you tend to go out the window. [...] You tend to spend all your time writing and the lecturer may be talking as you're writing but you're not listening.

Discussion of material in relation to practice experience was also found to be part of relevant instruction. Hearing the opinions of their classmates made the material 'more real' and helped understanding:

It's great when you can hear other people's opinions and views of the stuff. It makes the theories make more sense.

Debate and argument was considered to be particularly useful for understanding social science subjects:

And because there is such a fluid subject matter it is about argument. [... There is no theory that you have to learn off by heart. So it's kind of, on its own its fairly dry and it is only through debating it and arguing it is there any sense of it coming alive.

\section{Experiencing Success and Getting Feedback}

Anxiety about learning ability and performance in academic work is alleviated by receiving feedback that is seen as fair and correlates with grades, which in turn impacts on motivation to continue:

When you're getting feedback that is fair that's good and when your marks are coming back that you're happy with it encourages you to keep going.

I suppose half way through the year I really thought that I wasn't cut out to be a student. I felt I just can't do it and it was awful. I really was on the verge of packing it in and then I got my psychology results. That really gave me the boost that I needed at the time to confirm that I might not be able to do it all and understand it all but I can do it.

Wingate (2010) reports that negative and imperative comments when a low grade is received can have a negative impact on the self-efficacy and motivation of students. When formative feedback was seen as insensitive, unfocused or could not be understood students felt frustrated and demotivated:

I got one [assignment] back there recently. I wasn't sure what he was saying and I didn't go back to him. He kind of tore me apart in one way. Told me I wasn't putting 
sentences together right. I wasn't capable of or I didn't understand what I was about. There was no structure. Everything wasn't right and then again he said well it is alright for where you are. It wasn't that constructive.

Research indicates the importance of formative feedback in instructing students about expectations (Wingate, 2010; Brown, 2007) as well as fostering independent learning and skills (Brown, 2007; Hattie and Timperely, 2007). Regarding preferences for formative feedback, research indicates that students want clear suggestions on how to improve future work (Nicol, 2010; Ferguson, 2011) and comments which are specific rather than vague (Duncan, 2007; Brown, 2007).

Consistency and explicit grading was also an issue that caused frustration, which can interfere with students' improvement thus allowing them to experience success (Payne and Brown, 2011):

We'd read each other's stuff before it went in and after it came back and we looked at the marks. We just can't work out where the marks are going and what's getting the marks.

\section{Feeling Valued}

Adult students are reported to expect participation in class and sharing their experiences as acknowledgement of their adult status (Johnston and Merrill, 2004). A relationship is apparent between discussion being seen as a relevant form of instruction and the student feeling valued, particularly in relation to their adult standing:

I find at times that I'm being treated like a school kid in some classes and I don't particularly think I learn much from the session. In other classes I feel more relaxed and involved because there is room for discussion and questions.

Feeling valued was seen as being related to having practice experience and being treated as an adult suggesting that these students needed validation for their status as practitioners and adults:

The expectation is there that you know a certain amount of stuff. You're treated like an adult.

As well as their experience within the classroom, participants spoke about occasions outside of class where staff showed recognition of their feelings and supportive behaviour towards them, which they appreciated, in agreement with Frymier and Houser's (2000) finding that lecturers communicating in a "relational" way contribute to students' feelings of belongingness and their motivation to succeed:

She actually took me out of class. She said just before we start I want a word. And she was lovely. She said you look so stressed do you want to go to the office for five minutes. And she really put me at my ease 'cos I was up to high doh.

Speaking with my tutor, it makes college a bit more personal. 


\section{Encouraging Accurate Self-Awareness}

As students progressed through the transition into higher education they became more aware of their own strengths and abilities and compared themselves less to others in the class. They also took account of the time and effort they put into assignments and appreciated that they had to learn academic skills:

I done enough and I have to say I thought for myself that the marks reflected the amount of effort more or less I put in.

So far the essays have been good. Well I thought I did a reasonable job in them. I thought the marks weren't exceptionally good but they were relatively good but I thought the criticism of them was good. When I got them back I sat back and said to myself, okay you're only learning to do this again so you've got to give yourself a chance.

Students also began to see that social care work benefited from theoretical input agreeing with Dunworth's (2007, p. 155) assertion that a common finding in research on work-based learning in social work/social care work is becoming 'aware of the complexity of what was previously assumed to be instinctive or commonsense':

I'm certainly not cynical towards psychology as I may have been [... ]. I suppose I have to say that things like psychology that I'm far better able to engage in ideas. Like I don't have to agree with them but I would certainly take on board what they are saying.

However as discussed in McSweeney $(2011,2012)$ the view held of social care work and existing learning identity mediates. For example viewing social care work as a practical activity and seeing oneself as a practical person impacts on orientation towards subject matter:

We should be doing more of the subjects that are important for working with clients and less of sociology and stuff like that. That's just my opinion. Social care is practical and I am practical.

\section{Orientating Students to the Institution}

\section{Induction to the Institution}

'They need to become familiar with the roles, regulations, norms and expectations of the new institution. Institutions need to devote time to orientation, a process designed to help individuals know what is expected of them' (Anderson et al., 2012, p. 57). While students took part in a three day induction programme the week prior to beginning lectures some reported this to be overwhelming:

I did the three day induction which was quite good but it was difficult 'cos there was so much information and it was all new. Like it is interesting finding your way around the library but how much do you remember? It still took me a while to fit into the layout of the college.

Preparing students for the emotional and physical impact of the transition needs to be taken into account as well as preparing students for the practicalities of academic life. Some participants reported tiredness and increased emotionality: 
I'm just more busy and I'm more tired. I'm so tired these days that I could. I just want my mammy to make it all better. Just very weepy at times I find. It seems like I'll never get through this and it is really knocking on my self-esteem issues.

I'm struggling in some respects as in just the physical thing of getting up early in the morning and then staying until half five or six so it is a huge day.

Also it appears that the induction period was considered to be the only introduction necessary to prepare students for learning at this level without accounting for ongoing support such as the need to sustain 'energy and commitment' and intervene when students began to question their decision to partake (Anderson et al., 2012, p. 57).

\section{Awareness of Expectations}

Although the majority of participants entered the programme with prior further or higher education qualifications, for some the quantity and depth of the workload caused difficulties they did not expect, particularly fitting it in with work and home life:

When I went back to do my Level 2 training [Further Education Programme] it was grand. I did essays and I did exams. Now it was hard. It wasn't easy but college is completely different. Now I was looking forward to doing the course but I just find it is a lot of work. I'm finding the reading difficult. I just find I haven't the time in the day. You know I work fulltime and I have a home to run as well.

This suggests that new students need assistance in balancing their workload and managing their multiple responsibilities to avoid stress. Perhaps also greater consultation between different lecturers about the workload could help avoid undue pressure on students. Some students did learn to become more strategic and prioritise work themselves:

I was doing a lot more reading in the beginning. I've back peddled a bit on it and I find it better. I think I was flooding my brain. I was trying to do everything. But I've just realised that this isn't working. I was drowning in information so I said I'd back peddle a bit and concentrate on all the assignments and try and keep up a bit of reading in between. And I find that a lot better.

Ecclestone's (2004) study indicates that preparation for assignments so that students understand expectations and marking criteria allow students to gain procedural autonomy, thus feelings of safety and comfort in the academic setting. However, lack of clarity in expectations around assignments and little guidance have been reported in several studies of adult learners (e.g. MacDonald and Stratta, 1998; Inglis and Murphy, 1999; Leathwood and O'Connell, 2003). In the present study variability with regard to preparation for assignments is evident. Frustration is apparent when clear guidelines for assignments are not given, which could be exacerbated by the requirement to combine theoretical frameworks with practice reflection:

Yours I knew exactly what you wanted. I got it on the first week. I couldn't fault that. The only person I can blame is myself this time out on that. Other people are giving us work [and saying] ah don't worry about that. Ah just do dih, dih, dih. So I hand 
up something that is my idea of what you're giving out. Then it is no I wanted it more academic. Why did you not tell me that?

The theory practice relationship is not straightforward (Fealy, 1997; Eraut, 2003) and connecting theory and practice in written assignments is something that students report finding difficult, so expectations need to be clearly expressed to them in feedback also:

I couldn't understand the feedback I got. I thought I had done it right with lots of practice examples but he said I hadn't put enough theory into it. I don't know what theory should have been in it.

\section{Social Support}

Common with the findings of other studies of college students (Thompson, 2008; Thompson and Mazer, 2009; Walsh et al., 2009) and social work students (Wilks and Spivey, 2010) friends in the class group were reported to be a good source of different types of support. From the beginning a feeling of commonality, particularly when stressed, was important to participants:

A couple of weeks ago it was 'I have had enough of this'. Why am I doing this to myself? Then you go to college and hear that everyone is in the same boat. [....] Then you think I'm not doing so bad after all.

Some students formed study groups and helped each other with proof reading assignments, though this took time as participants did not mention doing this until the third interview:

[Name] would proof read my essays. And spellings and just like saying ah you'll be grand and reassurance.

We were a support group for each other. That was grand. Everything was discussed. However much joking we did when it came to essays, when it came to the exams and stuff there was huge discussions. Real serious like.

The slow development of relationships with peers was seen by participants as being due to the crowded timetable.

There isn't time for sitting around chatting and at the end of the day you see people running to get trains.

One of the things that has come up as a big thing for a lot of people is that interaction with people and learning from each other is severely curtailed.

The documented importance of peer relationships as a source of cognitive as well as socio-emotional support (Knapper and Cropley, 2000; Lazar, 1995) is something that needs to be considered. Taking into account students' preference for discussion and listening to the viewpoints of their peers along with findings that face-to-face interaction is the most widely used means of giving and receiving support (Thompson and Mazer, 2009) it suggests that teaching strategies that encourage peer collaboration and group solutions need to be used more. This enables engagement with course content, learning and relationship building (Yorke and Thomas, 2003). Milner and 
Criss (2006) report on the positive effects of developing "rituals" within class time for social work students in developing peer support. This had the result of lecturers being perceived as more caring too. Creating supportive strategies within the classroom is particularly important for adult learners where multiple roles and responsibilities do not allow much time to interact outside of class time (Ross-Gordon, 2003).

\section{Strategic Support}

Quinlan and O'Brodovich (1996) suggest that teaching staff should be aware of, and encourage students to make use of available support systems within the institution. The need for information about administrative and support systems was seen as particularly significant for these participants because of the little time spent in the college:

Like we're only here for one day a week. How the hell are we meant to know if our tutor doesn't know [...] about the forms for the exams that had to be signed and brought down to the office.

While it could be argued that students could find such information through sources such as the college website or bulletin boards, being told of such information personally would contribute to feelings of being valued by the institution.

Adult students may enter college with undiagnosed specific learning disabilities due to a lack of screening services when they were at school. The emotional impact of testing and diagnosis needs to be considered as an area where support can be required from staff members with whom the student has a relationship. One participant speaks about the effect of being tested for dyslexia:

I was really upset at the time. I knew it inside myself but knowing and actually having it confirmed is [pause]. Actually when I was doing the test I could see my school master shouting at me. Horrible. Telling me that I'm thick and whatever. Then I felt really stupid.

Due to their timetable students were unable to make use of workshops for mature students that provide assistance with academic skills. This suggests that for part-time students such support should be located within the department when possible, where it 'will take account of students needs and reduce possible frustrations' (Schulz and Szekeres, 2008, p. 263).

\section{Gains in Roles, Routines, Relationships and Identity}

By the end of their first year participants mentioned positive changes, either relating to themselves or to their work practices.

Due to the perceived value of higher education fitting with the cultural value put on education (Dunne, 2002; Share et al., 2007) some participants saw being in higher education as a personal achievement:

I feel a bit more [pause] this sounds silly. I feel a bit more important because I'm in college. 
I love walking into college. I love walking up the steps going I'm in college. The whole feeling of yes.

Others viewed education as equipping them with knowledge, which was equated with power:

Education is never wasted [...] people are learning and they're getting a bit more powerful with it.

In common with other research on social care education, such as Sargeant (2000) and Vatcher and Coles (2004), participants also saw gains being due to exposure to knowledge beyond workplace policies:

It makes you think beyond the box. I suppose I'd often look at it that we come in here [workplace] and we get bogged down in work. We don't look back and say why are we here and why are the kids here. In college it gives you time to do that.

I think education gives you time to reflect. Time to look at exactly what you do and why you do it.

Confirmation of existing good practices is also mentioned:

I feel satisfied to know that I'm doing my job right you know [ ... ] I got a sense of satisfaction out of that knowing that thirteen years was a long time to be in the job. In fact thankfully what I have been doing has been right.

Higher education is also reported to result in a gain in confidence in the workplace which has a positive impact on practice:

Doing the qualification does enhance your practice and your confidence because you know where the concepts are coming from.

I think it's having some impact on my confidence and relationships. When I'm confident it gives me the opportunity to interact more with clients and with the team.

As also reported by Forrester-Jones and Hatzidimitriadou (2006), with participants on a Certificate in Community Care Practice, participants in this study mentioned changes in their approach to work and clients, in particular becoming more clientcentred, as also found by Dunworth (2007) and Vatcher and Coles (2004):

I'm focusing on a more therapeutic approach and am more aware of how I'm feeling inside and how the kids may be affected by circumstances.

For me I work with fourteen to eighteen year olds. I never really considered their childhoods. [... ] We might get a lad at sixteen and a half or seventeen and we might only have him until nineteen, twenty. So you tend to approach him in a way that look whatever happened, happened. This is what we need to do to move on. [...] But I have to say that is what I'm enjoying. That these kids had a life and their parents had a life. At different stages things might have happened and it has affected where they are today.

I am more aware of what is going on for people. So it makes me understand them and it does make me more compassionate. 
Status differences between social care workers and social workers have been reported with the former feeling inferior due to the legal framework ${ }^{1}$, education and the low status of primary caring (Heron and Chakrabrati, 2002b; Milligan et al., 2004). Some participants view education as positively impacting on their confidence to overcome status differences:

Before I used to think the social workers are so much better than me but now I think we do different jobs but we're on the same level.

I know if I've to stay in this work I have to start dealing with these people [social workers] and I have to be on a par with them. And I know that more and more I feel on a par with them.

Finally, a positive outcome of education is seen as being able to express oneself more clearly so that you are listened to in the workplace:

My language has changed [... I'm able to give a viewpoint in a vocabulary that I possibly wouldn't have been able to do before

To kind of be able to hold that in a way where maybe a couple of years ago I would be just blurting it out and people going yeah, yeah whatever.

\section{Conclusions and Recommendations}

While the experiences of difficulties and supports encountered during the transition to higher education in this paper come from a sample of only fifteen participants many findings concur with other research conducted in higher education, social work and social care education.

While the transition to higher education inevitably causes some anxiety support within institutions should act to minimise it. The aim of professional educators is to enable students to create a viable identity to allow them to both experience success in the educational environment and integrate theoretical material with practice. The challenge of questioning and reflection on their existing roles as social care practitioners needs to be conducted in a environment where students feel safe and supported by both peers and educators (Bamber and Tett, 2000).

While by the end of the transition period all participants had "found their feet" and developed strategies for coping with academic demands and minimising stress, many went through periods of frustration and uncertainty that could have been reduced by the integration of supportive strategies within the institution.

Taking account of the expressed reluctance of the students to directly request support along with delays with students building supportive relationships with the peer group it is important that educators are aware of areas of potential anxiety and are proactive in developing supportive structures. A staggered induction period could help students to develop the skills and knowledge required to succeed in higher education, while helping lecturers keep in mind the time required to complete the transition to higher education.

The clear preference for the use of independent reading and discussion as a tool for learning along with difficulties expressed with a lecture format indicates that there is 
an opportunity for greater use to be made of this teaching strategy with adult social care students. Indeed the Higher Education Strategy Group (2011) advocates pedagogical practices that encourage critical thinking and stimulate active and independent learning. In addition these students come to college with valuable practice experiences that can be utilised in teaching and learning. To control the workload as well as facilitating the development of relationships with peers, some of the class time could be given over to the students working in groups with the lecturer available to assist. Integrating methods of enquiry based learning into the curriculum have been shown to encourage active learning, students' construction of knowledge and facilitate the transfer of knowledge between the workplace and college (Barrett, 2005). Reducing the pressure on themselves to cover a certain amount of material through lecturing may allow lecturers to communicate in a relational way with their students, getting to know students' names and showing that they care about their views and performance.

Knowledge of the expectations on assignments, understanding feedback and grades were areas which caused significant frustration and stress for these students. Since experiencing success increases self-efficacy, students benefit from clear written instructions about how to approach assignments to allow them to perform at their best. To learn from completed assignments, consistency in marking and consideration of students' understanding of the terminology used in giving feedback, along with appropriate examples, is required. As participants found it easier to understand their peers' language than that of lecturers perhaps peer review could be used in feedback. Peer assessment also has the advantages of familiarising students with marking criteria and encouraging a critical approach to knowledge (McConlogue, 2012).

Appropriately worded and sensitive feedback on assignments along with permitting lecturers time in class to build relationships with students through utilising a less didactic style sends students the message that they, their experience and their work is valued, increasing their sense of mastery, belongingness and interest in the content of the programme. Staff voicing their awareness of the possible physical and emotional impact of beginning a programme of higher education could also contribute to feelings of being understood and thus valued.

Part-time and adult students are juggling multiple roles so the clear relay of necessary information to students about issues such as examinations and timetable changes helps them plan and utilise their time. For part-time students in particular the location of support services such as academic skills workshops needs to be integrated into their usual timetable as many will not find the time to attend otherwise.

Overall what these students found supportive are factors associated with what Clegg (2010) refers to as a "culture of care", which fits with an academic identity. This, she points out is in opposition to the increasing drive towards managerialism within higher education institutions.

Finally, as differences between students and lecturers conceptualisation of "good teaching"(Reid and Johnston, 1999) and effective assessment practices (Maclellan, 2001; Joughlin 2010) have been documented, practitioner led research on students' experiences provides an opportunity to stand back from one's day-to-day work as a 
lecturer to "hear the stories" of one's partners in the learning process and thereby "understand, respect and respond to the ends that are important to them" (Rossiter, 1999, p. 67). This, in turn produces an opportunity for one's own professional development.

Note

[1] While the social care worker is the primary carer for a child in residential care the child's social worker is in a supervisory capacity with regard to the care of the child (Social Service Inspectorate, 2004).

\section{References}

Anderson, M. L., Goodman, J. \& Schlossberg, N. K. (2012) Counselling Adults in Transition: Linking Schlossberg's Theory with Practice in a Diverse World. ( $4^{\text {th }}$ ed.). Springer Publishing Co., New York.

Anglin, J. (1999) 'The uniqueness of child and youth care: a personal perspective', Child and Youth Care Forum, vol. 28, no. 2, pp. 143-150.

Bamber, J. \& Tett, L. (2000) 'Transforming the learning experiences of non-traditional students: a perspective from higher education', Studies in Continuing Education, vol. 22, no. 1, pp. 57-75.

Barrett, T. (2005) 'Understanding Problem-Based Learning', in Handbook of Enquiry and Problem Based Learning: Irish Case Studies and International Perspectives, eds T. Barrett, I. Mac Labhrainn \& H. Fallon, AISHE and CELT NUI Galway, Galway, pp. 13-26.

Baxter, A. \& Britton, C. (2001) 'Risk, identity and change: Becoming a mature student', International Studies in Sociology of Education, vol. 11, no. 1, pp. 87-102.

Bayes, K. (2009) Higher Aspirations Brighter Futures: Overview of the National Child Care Residential Initiative, Scottish Institute for Residential Child Care, Glasgow.

Bishop-Clark, C. \& Lynch, J. (1992) 'The mixed age college classroom', College Teaching, vol. 40, no. 3, pp. 114-117.

Brown, J. (2007) 'Feedback: The student perspective', Research in Post-compulsory Education, vol. 12, no. 1 , pp. 33-51.

Clegg, S. (2010) 'Academic identities for the 21st century', Key note paper presented at the 2nd International Conference focusing on Academic Identities, Glasgow, Scotland, 16-18 June.

Crimmens, D. (1998) 'Training for residential child care workers in Europe: Comparing approaches in The Netherlands, Ireland and the United Kingdom', Social Work Education, vol. 17, no. 30, pp. 309-320.

Davies, P. \& Williams, J. (2001) 'For me or not for me? Fragility and risk in mature students' decision-making', Higher Education Quarterly, vol. 55, no. 2, pp. 185-203.

Davies-Jones, H. (2000) The social pedagogues in Western Europe - some implications for European interprofessional care [online]. Available at: http://www.childrenuk.co.uk/chang/aug2000/ social_pedagogues.htm. (accessed 31 March 2008).

Donaldson, J. F., Flannery, D. \& Ross-Gordon, J. M. (1993) 'A triangulated study comparing adult college students' perceptions of effective teaching with those of traditional students', Continuing Higher Education Review, vol. 57, no. 3, pp. 147-163.

Duncan, N. (2007) “"Feed-forward”: Improving Students' Use of Tutors' Comments', Assessment \& Evaluation in Higher Education, vol. 32, no. 3, pp. 271-283.

Dunne, J. (2002) 'Citizenship and education: a crisis of the Republic?', in Reinventing Ireland: Culture, Society and the Global Economy, eds P. Kirby, L. Gibbons \& M. Cronin, Pluto Press, London, pp. 69-88. 
Dunworth, M. (2007) 'Growing your own: The practice outcomes of employment-based social work training. An evaluative case study of one agency's experience', Social Work Education, vol. 26, no. 3, pp. $151-168$.

Ecclestone, K. (2004) 'Learning in a comfort zone: comfort and cultural capital inside an outcomes based assessment scheme', Assessment in Education, vol. 11, no. 1, pp. 29-47.

Eraut, M. (2003) 'Editorial: the many meanings of theory and practice', Learning in Health and Social Care, vol. 2, no. 2, pp. 61-65.

Fealy, G. M. (1997) 'The theory-practice relationship in nursing: an exploration of contemporary discourse', Journal of Advanced Nursing, vol. 25, pp. 1061-1069.

Ferguson, P. (2011) 'Student perceptions of quality feedback in teacher education', Assessment \& Evaluation in Higher Education, vol. 36, no. 1, pp. 51-62.

Forrester-Jones, R. \& Hatzidimitriadou, E. (2006) 'Learning in the real world? Exploring widening participation: student views concerning the 'fit' between knowledge learnt and work practices', Assessment \& Evaluation in Higher Education, vol. 31, no. 6, pp. 611-624.

Frymier, A. B., Shulamn, G. M. \& Houser, M. (1996) 'The development of a learner empowerment measure', Communication Education, vol. 45, no. 3, pp. 181-199.

Frymier, A. B. \& Houser, M. L. (2000) 'The teacher-student relationship as an interpersonal relationship', Communication Education, vol. 49, no. 3, pp. 207-219.

Galatzer-Levy, I. R., Burton, C. L. \& Bonanno, G. A. (2012) 'Coping flexibility, potentially traumatic life events, and resilience: a prospective study of college student adjustment', Journal of Social and Clinical Psychology, vol. 31, no. 6, pp. 542-567.

Government of Ireland (2005) Health and Social Care Professionals Act, The Stationery Office, Dublin.

Hallstedt, P. \& Högström, M. (2005) The Recontextualisation of Social Pedagogy: A study of Three Curricula in the Netherlands, Norway and Ireland, PhD Thesis, Malmö, University of Malmö.

Hanafin, M. (2001) New Package for Social Care Professionals, Press Release from the Department of Health and Children [online]. Available at: http://www.maryhanafin.ie/socialcarepackage.htm (accessed 20 December 2006).

Hattie, J. \& Timperely, H. (2007) 'The power of feedback', Review of Educational Research, vol. 77, no. 1 , pp. $81-112$.

Heron, G. \& Chakrabarti, M. (2002a) 'Examining the perceptions and attitudes of staff working in community based children's homes: Are their needs being met?', Qualitative Social Work, vol. 1, no. 3, pp. 341-358.

Heron, G. \& Chakrabarti, M. (2002b) 'Impact of Scottish vocational qualifications on residential child care: have they fulfilled the promise?', Social Work Education, vol. 21, no. 2, pp. 183-197.

Higher Education Strategy Group (2011) National Strategy for Higher Education to 2030, Department of Education and Skills, Dublin.

Inglis, T. \& Murphy, M. (1999) No Room for Adults? A Study of Mature Students in University College Dublin, Brunswick Press Ltd., Dublin.

Jacklin, A. \& Le Riche, P. (2009) 'Reconceptualising student support: from 'support' to 'supportive", Studies in Higher Education, vol. 34, no. 7, pp. 735-749.

Johnston, R. \& Merrill, B. (2004) 'From old to new learning identities: charting the change for nontraditional adult students in higher education', Paper presented at the 2004 ESREA Conference, Wroclaw, Poland, 16-19 September [online]. Available at: http://ersea2004. dawid.uni.wroc.pl/papers/65.doc, (accessed 13 January 2007).

Joughin, G. (2010) 'The hidden curriculum revisited: a critical review of research into the influence of summative assessment on learning', Assessment and Evaluation in Higher Education, vol. 35, no. 3, pp. 335-345.

Knapper, C. K. \& Cropley, A. J. (2000) Lifelong Learning in Higher Education. $3^{\text {rd }}$ edn. Kogan Page Ltd., London. 
Knorth, E. J., Klomp, M., Van den Bergh, P. \& Noom, M. J. (2007) 'Aggressive adolescents in residential care: A selective review of treatment requirements and models', Adolescence, vol. 42, no. 167 , pp. 461-485.

Lazar, A. M. (1995) 'Who is studying in groups and why?', College Teaching, vol. 43, no. 2, pp. 61-65.

Leathwood, C. \& O'Connell, P. (2003) 'It's a struggle: the construction of the 'new student' in higher education', Journal of Education Policy, vol. 18, no. 6, pp. 597-615.

Leder, G. C. \& Forgasz, H. J. (2004) 'Australian and international mature students: The daily challenges', Higher Education Research and Development, vol. 23, no. 2, pp. 183-198.

Lundberg, C. A., McIntire, D. D. \& Creasman, C. T. (2008) 'Sources of social support and self-efficacy for adult students', Journal of College Counselling, vol. 11, no. 1, pp. 58-72.

MacDonald, C. \& Stratta, E. (1998) 'Academic work, gender and subjectivity: mature non-standard entrants in higher education', Studies in the Education of Adults, vol. 30, no. 1, pp. 67-79 [online]. Available at: http://search.ebscohost.com.libezproxy.open.ac.uk/login.aspx? direct1/4true\&db1/4a9h\&an1/454941\&site1/4ehost-live\&scope1/4site">http://libezproxy. open.ac.uk/login?url1/4http://search.ebscohost.com.libezproxy.open.ac.uk/login.aspx?direct1/ 4true\&db1/4a9h\&AN1/454941\&site1/4ehost-live\&scope1/4site (accessed 17 September 2005).

Maclellan, E. (2001) 'Assessment for learning: The different perceptions of tutors and students', Assessment and Evaluation in Higher Education, vol. 26, no. 4, pp. 307-318.

McConologue, T. (2012) 'But is it fair? Developing students' understanding of grading complex written work through peer assessment', Assessment \& Evaluation in Higher Education, vol. 37, no. 1, pp. 113-123.

McLeod, J. (2001) Qualitative Research in Counselling and Psychotherapy, Sage Publications, London.

McSweeney, F. (2011) Learning for Work: Social Identities and Professional Education in Social Care, VDM Verlag Dr. Muller, Saarbrucken.

McSweeney, F. (2012) 'Student, Practitioner or Both? Separation and Integration of Identities in Professional Social Care Education', Social Work Education: The International Journal, vol. 31, no. 3, pp. 364-382.

Martin, K. (2003) 'Student support in work-based learning: interpreting cultural differences', Symposium Paper presented to the Scottish Educational Research Conferences, Perth, Scotland, November 2003 [online]. Available at: http://www.leeds.ac.uk/educol/documents/00003478. doc (accessed 24 July 2006).

Merrill, B. (1999) Gender, Change and Identity: Mature Women Students in Universities, Aldershot, Hans, Asgate.

Merrill, B. (2001) 'Learning and teaching in universities: perspectives from adult learners and lecturers', Teaching in Higher Education, vol. 6, no. 1, pp. 5-17.

Migletti, C. L. \& Strange, C. C. (1998) 'Learning styles, classroom environment preferences, teaching styles and remedial course outcomes for underprepared students at a two year college', Community College Review, vol. 98, no. 1, pp. 1-19.

Milligan, I., Kendrick, A. \& Avan, G. (2004) A Survey of Job Satisfaction, Staff Morale and Qualifications in Residential Child Care in Scotland, Scottish Institute of Residential Child Care, University of Strathclyde.

Milner, M. \& Criss, P. (2006) 'Use of spiritual practices and classroom rituals of connection to reduce impact of stress in social work students', Paper presented at NACSW Convention, Philadelphia, October 2006 [online]. Available at: www.nacsw.org/Publications/.../ MilnerMSpiritualPracticesE.pdf (accessed 17 July 2012).

Moore, E. (2004) 'Changing educational identities of non-traditional adult university graduates', Paper presented at ESREA 2004 Conference, Wroclaw, Poland, 16-19 September [online]. Available at: http://ersea2004.dawid.uni.wroc.pl/papers/22a.rtf (accessed 12 January 2007).

Murphy, M. \& Fleming, T. (1998) 'College knowledge: power, policy and the mature student experience at university', Paper presented at the 28th Annual SCUTREA Conference, 
University of Exeter, 6-8 July [online]. Available at: http://www.leeds.ac.uk/educol/ documents/000000733.doc (accessed 2 February 2007).

National Qualifications Authority of Ireland (2005) Qualifications can Cross Boundaries [online]. Available at: http://www.nqai.ie/docs/publications/UK_comparison_guide.pdf (accessed 16 November 2012).

Nicol, D. (2010) 'From monologue to dialogue: improving written feedback processes in mass higher education', Assessment \& Evaluation in Higher Education, vol. 35, no. 5, pp. 501-517.

Payne, E. \& Brown, G. (2011) 'Communication and practice with examination criteria: Does this influence performance in examinations', Assessment \& Evaluation in Higher Education, vol. 36, no. 6 , pp. 619-626.

Pearlin, L. I. \& Schooler, C. (1978) 'The structure of coping', Journal of Health and Social Behaviour, vol. 19 , no. 1 , pp. $2-21$.

Pollard, A. (2003) 'Learning through life - higher education and the lifecourse of individuals', in Higher Education and the Lifecourse, eds M. Slowey \& D. Watson, SRHE and Open University Press, Maidenhead, pp. 167-185.

Quinlan, K. \& O'Brodovich, K. (1996) 'Transitional support for adult vocational learners: A review of institutional roles', Journal of Employment Counselling, vol. 33, pp. 174-189.

Ramsay, S., Jones, E. \& Barker, M. (2007) 'Relationship between adjustment and support types: Young and mature-aged local and international first year university students', Higher Education, vol. 54, no. 2, pp. 247-264.

Reid, D. J. \& Johnston, M. (1999) 'Improving teaching in higher education: Student and teacher perspectives', Educational Studies, vol. 25, no. 3, pp. 269-281.

Richardson, V. (1996) 'Training of staff working with children in care', in Focus Ireland, Focus on Residential Care in Ireland: 25 years since the Kennedy report Conference Proceedings, $5^{\text {th }}-6^{\text {th }}$ March 1996, Focus Ireland, Dublin, pp. 48-51.

Ross-Gordon, J. M. (2003) 'Adult learners in the classroom', New Directions for Student Services, vol. 102, pp. 43-52.

Ross-Gordon, J. M. \& Brown Haywood, F. (2000) 'Keys to college success: as seen through the eyes of African-American adult students', The Journal of Continuing Higher Education, vol. 48, no. 3, pp. $14-23$.

Sargeant, A. V. (2000) 'An exploratory study of the effects of progression towards National Vocational Qualifications on the occupational knowledge and care practice of social care workers', Social Work Education, vol. 19, no. 6, pp. 639-661.

Seale, C. (1998) 'Qualitative interviewing', in Researching Society and Culture, ed. C. Seale, Sage, London, pp. 202-216.

Schlossberg, N. K. (1989) Overwhelmed: Coping with Life's Ups and Downs, Lexington, Toronto.

Schulz, L. \& Szekeres, J. (2008) 'Service provision to students: Where the gown best fits', Journal of Higher Educational Policy and Management, vol. 30, no. 3, pp. 261-271.

Share, P., Tovey, H. \& Corcoran, M. P. (2007) A Sociology of Ireland. 3rd edn. Gill \& McMillan, Dublin.

Smith, M. (2003) 'Towards a professional identity and knowledge base: Is residential child care still social work?', Journal of Social Work, vol. 3, no. 2, pp. 235-252.

Social Services Inspectorate (2004) Annual Report, Social Services Inspectorate, Dublin.

Stevens, G. (2003) 'Late studentship: Academic aspiration, personal growth and the death of the past', Journal of Phenomenological Psychology, vol. 34, no. 2, pp. 235-256.

Sutherland, P. (1999) 'A study of the learning of mature adult students on a professional course', Journal of Further and Higher Education, vol. 23, no. 3, pp. 381-389.

Thompson, B. (2008) 'How college freshmen communicate student academic support: A grounded theory study', Communication Education, vol. 57, no. 1, pp. 123-144. 
Thompson, B. \& Mazer, J. P. (2009) 'College student ratings of student academic support: frequency, importance, and modes of communication', Communication Education, vol. 58, no. 3, pp. 433-458.

Tones, M., Fraser, J., Edler, R. \& White, K. M. (2009) 'Supporting mature-aged students from a low socioeconomic background', Higher Education, vol. 58, no. 4, pp. 505-529.

Uí Chasaide, C. (1997) 'Balancing Realities - The act of becoming an adult student', in Mature Students in Higher Education: Proceedings of conference in Athlone RTC, March 1996, ed. R. Morris, Higher Education Equality Unit, Cork, pp. 35-48.

Vatcher, A. \& Coles, J. (2004) 'The empowering practice programme at the University of the West of England', Learning Disability Review, vol. 9, no. 3, pp. 4-13.

Verger, P., Combes, J., Kovess-Masfety, V., Choquet, M., Guagliardo, V., Rouillon, F. \& Peretti-Wattel, P. (2009) 'Psychological distress in first year university students: socioeconomic and academic stressors, mastery and social support in young men and women', Social Psychiatry and Psychiatric Epidemiology, vol. 44, no. 8, pp. 643-650.

Walsh, C., Larsen, C. \& Parry, D. (2009) 'Academic tutors at the frontline of student support in a cohort of students succeeding in higher education', Educational Studies, vol. 35, no. 4, pp. $405-424$.

Wingate, U. (2010) 'The impact of formative feedback on the development of academic writing', Assessment \& Evaluation in Higher Education, vol. 35, no. 5, pp. 519-533.

Wilks, S. E. \& Spivey, C. A. (2010) 'Resilience in undergraduate social work students: Social support and adjustment to academic stress', Social Work Education, vol. 29, no. 3, pp. 276-288.

Yorke, M. \& Thomas, L. (2003) 'Improving the retention of students from lower socio-economic groups', Journal of Higher Education Policy and Management, vol. 25, no. 1, pp. 63-75. 